\title{
In vivo assessment of oxidative stress in heart cells of Cirrhinus mrigala (Hamilton, 1822) challenged with sublethal doses of Aeromonas hydrophila
}

\author{
SRIPARNA DATTA RAY AND SUMIT HOMECHAUDHURI* \\ Aquatic Bioresource Research Laboratory, Department of Zoology, University of Calcutta, Kolkata - 700019 \\ West Bengal, India \\ *Postgraduate Department of Zoology, Asutosh College, Kolkata - 700 026, West Bengal, India \\ e-mail: sumithomechaudhuri@gmail.com
}

\begin{abstract}
Experiment was performed to study the effect of Aeromonas hydrophila MTCC 646 on the heart of Cirrhinus mrigala (Hamilton, 1822). The in vivo innate immune response was also monitored in these fishes. Fishes were inoculated with 3 asymptomatic doses $\left(2 \times 10^{5}, 2 \times 10^{6}\right.$ and $\left.2 \times 10^{7} \mathrm{CFU} \mathrm{ml}{ }^{-1}\right)$ intraperitoneally (i.p.) @ $0.5 \mathrm{ml} 100 \mathrm{~g}^{-1}$. Dose dependent pattern of change was observed in the immune biomarkers chosen for the study. Histopathology revealed endocarditis and cell death identified as apoptosis. The percentage contribution of late apoptotic cells was $0.36 \%$ after 7 days in fish heart exposed to the highest dose of bacteria which was reduced to $0.01 \%$ after 30 days. Oxidative stress and dosage were directly proportional. The oxidised dichloro fluorescein peak was about 4.05 fold more than the control samples, after 7 days with respect to the highest dose and immune responses helped to decrease the mean peak to 1.02 after 30 days, signifying recovery of phagocytic activity, which is a part of the reticulo-endothelial system. This work presents an insight into the immune response and the results analysed statistically show that there was significant difference between percent population of early apoptotic cells $(\mathrm{p}<0.05)$ collected after 7 days and 30 days duration with respect to all the three doses.
\end{abstract}

Keywords: Aeromonas hydrophila, Apoptosis, Cirrhinus mrigala, Histopathology, Immune response, Reactive oxygen species

\section{Introduction}

Population growth in the subcontinent over the last few decades and a concomitant need for food to support this populace have made India one of the sixteen Low-Income Food Deficit Countries (LIFDC) in the world (FAO, 2016). With an aim to provide food in the form of cheap animal protein, aquaculture has become an increasingly important source of sustainable food production in India. The recent expansion of intensive aquaculture practices thus has led to several fish diseases. As a result, aquaculture industry suffers heavy financial losses, mainly due to uncontrolled microbial diseases resulting in mass mortalities (Shao, 2001; Wahli et al., 2002; Saksida et al., 2007; Almeida et al., 2009). Several factors are responsible for such disease outbreaks viz., environmental conditions, excess feeding, improper rearing methods, water temperature, bacterial growth, irregular water renewal and improper removal of wounded and dead fish from the farming area.

One of the major bacterial diseases causing diseases in Indian major carps (IMCs) is Aeromoniasis caused by Aeromonas hydrophila, an ubiquitous Gram negative motile bacterium responsible for primary or stress associated pathogenicity in warm and cold water fishes (Harikrishnan et al., 2005; Daskalov, 2006). Dermal ulceration, tail rot, erythrodermatitis, haemorrhagic septicemia, red sore and scale protrusion are important pathological conditions accredited to members of A. hydrophila (Saha and Pal, 2000; Dash et al., 2008). Aeromonads are also known as potent causative agents of a wide range of diseases in man and other animals (Ghenghesh et al., 2008). It is already enlisted in the Contaminant Candidate List and the Environmental Protection Agency has validated its detection and enumeration in drinking water system (USEPA, 2001).

Studies on innate immune response mechanisms against $A$. hydrophila have been carried out extensively in several fish species (Sahu et al., 2007; Rodríguez et al., 2008; Reyes et al., 2011). It is evident that immune defense mechanisms play a critical role in preventing bacterial disease in fishes (Mohanty et al., 2007). Several authors have documented such changes in immune parameters in fish exposed to an array of pathogens (Raida and Buchmann, 2008; 2009; Mohanty and Sahoo, 2010). The host pathogen interaction with special emphasis to A. hydrophila has been documented in fishes from various parts of India (Saha and Pal, 2000; Vivekanadhan et al., 2005; Dash et al., 2008).

In fishes, the innate immunity is an indispensable component in fighting pathogens. The present study assessed the oxidative stress in heart tissue of the IMC 
Cirrhinus mrigala (Hamilton, 1822). C. mrigala is one of the commercially important species of IMCs. These fishes were challenged with three asymptomatic doses of A. hydrophila and the impact of oxidative stress in the heart tissue was investigated. Gross changes were studied at the histopathology level. Reactive oxygen species (ROS) were originally thought to be released only by phagocytic cells during their role in host defense. It is now clear that ROS have a cell signaling role in many biological systems, both in plants and animals (Bolwell et al., 1995; Gamaley and Klyubin, 1999). ROS induces programmed cell death or apoptosis, induce or suppress the expression of many genes and activate cell signaling molecules and cascades such as those involving mitogen activated protein kinase (Oter, 2012). Hence, the ROS was quantitated and the extent of damage caused by ROS in fish heart was investigated using high throughput techniques like flow cytometry. Selected innate immune parameters in these cells were also studied.

\section{Materials and methods}

\section{Bacterial culture}

Bacterial strain A. hydrophila MTCC 646, a potent fish pathogen, procured from Microbial Type Culture Collection and Gene Bank (MTCC), Institute of Microbial Technology (IMTECH), Chandigarh, India was used in this study. It was received as a lyophilised culture and was subsequently revived by adding nutrient broth (NB) (at $37^{\circ} \mathrm{C}$ for $24 \mathrm{~h}$ ) and transferring the rehydrated culture to nutrient agar medium. Consequently, streak plate method was followed to get isolated pure bacterial colonies. The bacteria was cultured in nutrient broth for preparation of inoculua for the study.

\section{Fish and experimental condition}

C. mrigala $(30 \pm 2$ g average body weight and $15 \pm 2 \mathrm{~cm}$ average body length) were collected from a local fish farm, Matsyajibi Samabyay Samity, Anandapur, Kolkata, West Bengal, India. The fishes were acclimatised in the laboratory for 7 days and were fed with Tubifex. Water quality parameters were regularly monitored. Water temperature was maintained at $26 \pm 2{ }^{\circ} \mathrm{C}$. Water was renewed everyday to avoid accumulation of unutilised food and metabolic waste products.

The fishes were devided into four groups of 10 fish each and each group had 6 replicates. The first group served as the sham injected control (Dose 0) and the remaining three groups contained fishes intraperitoneally injected with three sublethal doses of $A$. hydrophilla viz., $2 \times 10^{5} \mathrm{CFU} \mathrm{ml} \mathrm{m}^{-1}$ (Dose 1); $2 \times 10^{6} \mathrm{CFU} \mathrm{ml}^{-1}$ (Dose 2) and $2 \times 10^{7} \mathrm{CFU} \mathrm{ml}{ }^{-1}$ (Dose 3 ). The biomarkers chosen for the present study were evaluated after a duration of 7 days and 30 days independently. Altogether, there were 480 fish samples that were used in this study, 240 samples at 7 days and 30 days post-challenge respectively.

Artificial inoculation of fishes with A. hydrophila

The bacterial strain MTCC 646 was cultured in nutrient broth (NB) and incubated at $37^{\circ} \mathrm{C}$ for $24 \mathrm{~h}$ prior to artificial inoculation in fishes. Bacterial cells were harvested by centrifugation at $5000 \mathrm{~g}$ for $5 \mathrm{~min}$ and washed in physiological saline, PS $(0.85 \% \mathrm{NaCl})$. The strain was enumerated by correlating the OD value taken at $600 \mathrm{~nm}$ of the growing culture with the corresponding colony forming units (CFU) obtained by spread plate dilution method (Ref: OD $600 \mathrm{~nm} \mathrm{1}=2 \times 10^{9} \mathrm{CFU} \mathrm{ml}^{-1}$ ), following Pal and Pradhan (1990). Three sub-lethal concentrations $(2 \mathrm{x}$ $10^{5} \mathrm{CFU} \mathrm{ml}^{-1}, 2 \times 10^{6} \mathrm{CFU} \mathrm{ml}^{-1}$ and $2 \times 10^{7} \mathrm{CFU} \mathrm{ml}^{-1}$ ) were prepared in PS (working volume: $0.5 \mathrm{ml}$ per $100 \mathrm{~g}^{-1}$ body weight of fish) and injected intraperitoneally (i.p.) into six replicates of test fish (each replicate containing 10 fishes). Potential fish biomarkers were screened on the $7^{\text {th }}$ and $30^{\text {th }}$ day post-challege and compared with corresponding sham injected control groups (six replicates, each containing10 fishes injected with sterile PS only).

\section{Histopathology}

Fish samples were dissected and the heart tissues collected were fixed in aqueous Bouin's fluid for $24 \mathrm{~h}$. Then, the tissue was dehydrated in graded alcohol series, immersed in cedar wood oil followed by embedding in molten paraffin (melting point: $56-58^{\circ} \mathrm{C}$ ). Serial sections were cut at $5-7 \mu \mathrm{m}$. Sections were stained in Haematoxylin-Eosin (Bancroft and Stevens, 1990). Photomicrographs were taken in Olympus BX 51 compound microscope under oil immersion objective for further study.

\section{Estimation of intracellular ROS}

Heart tissue was treated with collagenase I $\left(2 \mathrm{mg} \mathrm{ml}^{-1}\right)$ and single cell suspensions were prepared by constant shaking at $37^{\circ} \mathrm{C}$. ROS generation was recorded in these cells following the method of Datta Ray and Homechaudhuri (2014), in which cells were stained with 2'- 7'-Dichlorodihydrofluorescein diacetate (DCFDA) in a $\mathrm{Ca}^{2+}$ enriched binding buffer and analysed by flow cytometry. The mean values were considered and the data were analysed using BD Cell Quest Pro software from Becton Dickinson (Datta Ray and Homechaudhuri, 2014).

\section{Annexin V/PI study}

Single cell suspensions were prepared from the fish heart following Datta Ray and Homechaudhuri (2014). Annexin V/PI study was performed with these cells to interpret the nature of cell death. Cells were stained for 
30 min at room temperature in dark with FITC conjugated Annexin $\mathrm{V}$ and $\mathrm{PI}$ in a $\mathrm{Ca}^{2+}$ enriched binding buffer and were analysed by flow cytometry.

\section{Statistical analysis}

One way Univariate Analysis of Variance (ANOVA) at $5 \%$ level of significance $(\mathrm{p}<0.05$ at $\mathrm{df}=3,36)$ and Duncan's post-hoc test was also performed to identify the homogenous means, if any, using SPSS Statistics 24. Paired $\mathrm{t}$ - test was performed between observations made after 7 days and 30 days in fishes exposed to three different doses of $A$. hydrophila $(\mathrm{p}<0.05)$ (Zar, 1999).

\section{Results and discussion}

\section{Histopathology}

The heart in C. mrigala is situated inside the pericardium and is placed anterior to the main body cavity and ventral to the pharynx. Earlier studies have shown that the atrium has a thin wall and muscular trabeculae traverses the lumen as a loose meshwork. The endothelial lining is large in area and has a phagocytic activity as part of the reticuloendothelial system. The ventricle is thicker than the atrium and normal histological sections reveal the presence of only a minimal lumen (Genten et al., 2009).

Comparative study of heart tissue sections of control and A. hydrophila challenged fish samples revealed that the gross structure almost remained the same among them. The treated fishes did not show any cellular damage. However, the cardiomyocytes were affected due to the oxidative stress generated by the pathogenic effect of A. hydrophila. Fig. 1a shows the atrium which is thin walled, spongy in nature and shows numerous spaces filled with erythrocytes. The endothelial lining is large in area and shows phagocytic activity as part of the reticuloendothelial system. Contraction of the atrium forces the blood through valves into the ventricle. Fig. $1 \mathrm{~b}$ shows the ventricular cardiomyocytes. In some cardiomyocytes, thin elongated nuclei located centrally and dense nuclei of the endocardium, the innermost layer of the heart, are also seen. Arrows indicate the nuclei of cardiomyocyte (straight arrow) and endocardium (bent arrow) respectively.

Histopathology of heart has served as a potent fish biomarker in several studies performed by scientists in various parts of the world since decades (Steinbach et al., 2016). Ventura and Grizzle (1988) and Huizinga et al. (1979) have independently reported necrotic foci, slight inflammation, oedema and minor focal necrosis in heart of Ictalurus punctatus and Micropterus salmoides infected with $A$. hydrophila. Adult zebrafish and Lake Victoria cichlids (Haplochromis piceatus) when subjected to chronic hypoxia have shown histopathogical changes in heart. These included reduced ventricular outflow tracts and reduced lacunae surrounding trabeculae (Marques et al., 2008). Quantitation of myocyte nuclei in both species also revealed that, relative to controls, hypoxic fish had increased numbers of nuclei per unit area.

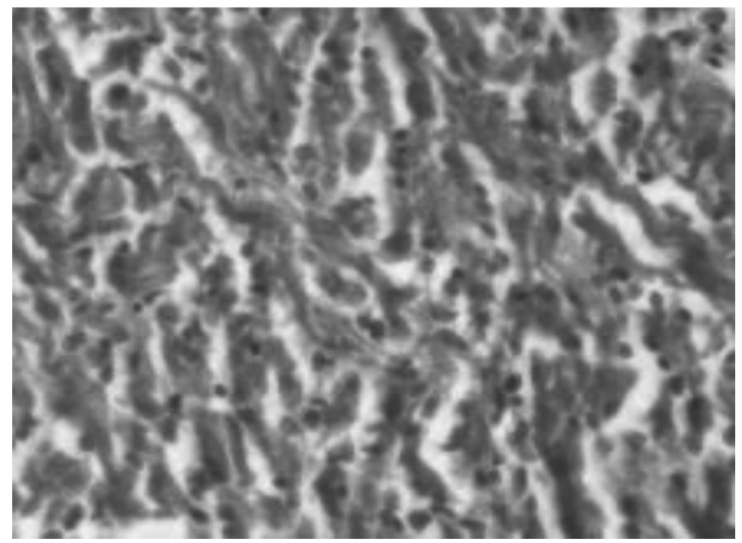

Fig. 1a. Histopathology of heart in C. mrigala control sample (H and $\mathrm{E} ; \mathrm{x} 600)$

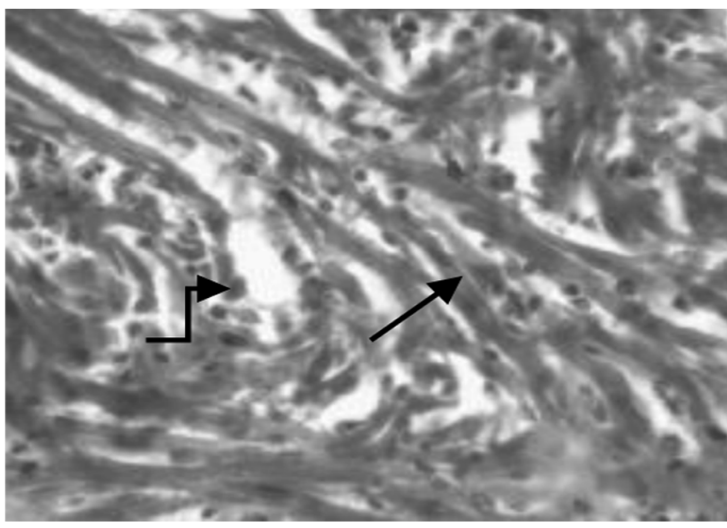

Fig. 1b. Histopathology of heart in C. mrigala challenged with A. hydrophila (H\&E; x 600)

Although a detailed description of haematological changes coupled with oxidative stress is beyond the scope of this article, many citations clearly indicate that stressors such as handling, crowding, capture, restrain, hypoxia, anaesthesia, air exposure and sampling techniques can affect fish haematology and/or clinical chemistry values (Ellsaesser and Clem, 1987; Groff and Zinkl, 1999; Greenwell et al., 2003; Dror et al., 2006; Gbore et al., 2006; Scott and Ellis, 2007). Studies revealed that multiorgan and systemic stress responses include alterations (often decreases) in body condition and/or organ weights, with corresponding histopathological changes such as atrophy 
of adipose tissue (fat), skeletal and cardiac muscle and liver cells, among other tissue types.

\section{Estimation of oxidative stress in heart}

The potential role of $A$. hydrophila in generation of oxidative stress in terms of intracellular ROS production and its fate following a one month recovery period was analysed by flow cytometry. Single cell suspensions prepared from heart of $C$. mrigala exposed to the four different doses (Dose 0,1, 2 and 3 respectively) were labeled with $2^{\prime}-7^{\prime}$ - Dichloro dihydro fluorescein diacetate ( $\mathrm{H}_{2}$-DCFDA). Results obtained after a span of 7 days of artificial inoculation showed an approximate 1.50, 2.59 and 4.05 fold increase of the oxidized dichloro fluorescein (DCF) mean peak in case of fishes injected with Dose 1, 2 and 3 respectively, compared to the control (Dose 0 ). This is a clear indication of elevated ROS generation in the treated fishes in comparison to the control.

After a span of 30 days post-challenge, during which the fishes were maintained in a stress free condition, the ROS was quantitated again and results showed 0.96, 1.02 and 1.03 fold increase in the DCF mean peak in case of fishes injected with Dose 1, 2 and 3 respectively, compared to the control (Dose 0). Thus, it can be inferred that a series of innate immune responses were elicited within the fish which tries to combat a carrier state bacterial infection and restores the equilibrium with special emphasis to the redox state of the body.

Intracellular changes with reference to the generation of ROS in the single cell suspensions prepared from fish heart have been analysed statistically to construe the observations made at the cellular level. The oxidative stress in terms of ROS have been quantified in the fishes injected with three different doses of bacteria after 7 days and 30 days respectively. Sham injected control was considered in each case. The mean \pm SE values are presented in Table 1. Significant difference was found in
ROS generated in C. mrigala injected with four different doses (Sham injected control, $2 \times 10^{5} \mathrm{CFU} \mathrm{ml}^{-1}, 2 \times 10^{6}$ $\mathrm{CFU} \mathrm{ml} \mathrm{m}^{-1}$ and $\left.2 \times 10^{7} \mathrm{CFU} \mathrm{ml}^{-1}\right)(\mathrm{p}<0.05)$.

When results obtained after 7 days were analysed by Duncan's post hoc test for homogeneity, showed presence of 4 subsets. This indicates that there was a significant difference in the generation of ROS with respect to all the four doses when they were compared pair-wise. However, when the same study was performed with results obtained after 30 days, only a single subset was obtained indicating that there is no significant difference in the amount of ROS generation in fishes injected with Dose $0,1,2$ and 3 respectively.

The generation of ROS in heart cells is an act of self defense, as part of the innate immune response generated in fishes when they are subjected to pathogenic infection. When ROS was estimated after 30 days post-challenge, the amount of ROS generation was meagre in contrast to the initial amount of oxidative stress. It is pertinent to mention here that the antioxidative stress enzyme pathway which results in the increased activity and concentrations of all the stress enzymes viz., SOD, CAT, GPx, GR and GSH plays a crucial role in combating the increased level of ROS production within the cardiomyocytes to prevent the deleterious effects of the oxidative stress generated due to the pathogenic effect of $A$. hydrophila which was injected at three asymptomatic carrier state dosages.

\section{Study of cell death and nature of innate immune response}

Histopathology revealed certain cellular damage in cardiomyocytes of treated samples in comparison to sham injected control which appeared normal. Cell damage was also associated with reported cell death, analysed by trypan blue dye exclusion test for cell viability. The maximum extent of such damage was observed in fishes exposed to the highest dose of the pathogen (Dose 3: $2 \times 10^{7} \mathrm{CFU} \mathrm{ml}^{-1}$ ) in comparison to Dose 1 and 2. Further study was taken

Table 1. Changes in oxidative stress measured by the quantification of ROS in single cell suspensions of heart cells of C. mrigala due to experimental inoculation of sub-lethal doses A. hydrophila (MTCC 646) at 7 and 30 days post-challenge. Dose of bacteria were given@0.5 ml $100 \mathrm{~g}^{-1}$ body weight of fish

\begin{tabular}{lll}
\hline Sampling day & A. hydrophila dose & Mean \pm SE \\
\hline 7 days post-challenge & Dose $0($ Sham injected control $)$ & $11.76 \pm 0.01^{\mathrm{a}}$ \\
& Dose $1\left(2 \times 10^{5} \mathrm{CFU} \mathrm{ml} l^{-1}\right.$ & $17.7 \pm 0.01^{\mathrm{b}}$ \\
& Dose $2\left(2 \times 10^{6} \mathrm{CFU} \mathrm{ml}^{-1}\right)$ & $30.51 \pm 0.01^{\mathrm{c}}$ \\
& Dose $3\left(2 \times 10^{7} \mathrm{CFU} \mathrm{ml}^{-1}\right)$ & $47.63 \pm 0.02^{\mathrm{d}}$ \\
\hline 30 days post-challenge & Dose $0($ Sham injected control $)$ & $11.66 \pm 0.01^{\text {aa }}$ \\
& Dose $1\left(10^{5} \mathrm{CFU} \mathrm{ml}^{-1}\right)$ & $11.24 \pm 0.01^{\text {aa }}$ \\
& Dose $2\left(2 \times 10^{6} \mathrm{CFU} \mathrm{ml}^{-1}\right)$ & $11.97 \pm 0.01^{\text {aa }}$ \\
& Dose $3\left(2 \times 10^{7} \mathrm{CFU} \mathrm{ml} l^{-1}\right)$ & $12.08 \pm 0.02^{\text {aa }}$ \\
\hline
\end{tabular}

Values are expressed as Mean $\_\mathrm{SE} ; \mathrm{n}=480$; similar alphabets within column denote homogeneous means $(\mathrm{p}<0.05)$ due to Duncan's post hoc test, $\alpha=0.05$ 
up to ascertain the nature of such cell death (apoptosis) that was observed among the cardiomyocytes by flow cytometric analysis.

Flowcytometric study revealed the presence of 3 sub-population of cells in the cytogram viz., normal cells (Annexin $\mathrm{V}^{-} / \mathrm{PI}^{-}$), early apoptotic cells (Annexin $\mathrm{V}^{+} / \mathrm{PI}^{-}$) and late apoptotic cells (Annexin $\mathrm{V}^{+} / \mathrm{PI}^{+}$). This analysis was done initially after 7 days and was then repeated after 30 days of recovery period to ascertain the extent of damage that was caused initially and the intensity of innate immune response that was triggered inside the host body to combat the pathogenic infection that was caused by the artificial inoculation of the pathogen (Table 2a).

Dot plots enumerate the increase of apoptotic cells among treated fishes in comparison to control. The amounts of normal and healthy cells were 99.95, 98.92, 98.42 and $97.72 \%$ for control, fishes injected with Dose 1 , 2 and 3 respectively. The amounts of early apoptotic cells were $0.25,0.96,1.54$ and $2.16 \%$ for control, fishes injected with Dose 1, 2 and 3 respectively and the amounts of late apoptotic cells were $0.04,0.12,0.12$ and $0.36 \%$ for the same doses respectively. At lower doses (Dose 1 and 2), the amounts of early and late apoptotic populations were less significant but upon increment of dose, the amount of apoptotic population increased dramatically.

After 30 days of recovery, the percentage of normal healthy cells increased to about $99.97,99.83$ and $99.49 \%$ in case of fishes injected with Dose 1, 2 and 3 respectively while in sham injected control cells, the percentage of normal cells were 99.94. The number of early apoptotic cells decreased to $0.02,0.17$ and $0.51 \%$ in fishes injected with Dose 1, 2 and 3 respectively, while sham injected control showed a meagre $0.01 \%$ of early apoptotic cells. Similarly, the percentage of late apoptotic cells also became very low, approximately $0.01,0.00$ and $0.01 \%$ for fishes injected with Dose 1, 2 and 3 respectively while the control samples showed $0 \%$ of such cell types.

Results of the present study shows that $A$. hydrophila is capable of inducing apoptosis in heart of C. mrigala and the extent of damage caused is directly proportional to the bacterial dose injected. There was a clear dose dependent pattern of damage. The contribution of $99.95 \%$ of normal cells in sham injected control declined to $97.72 \%$ in fishes subjected to the highest dose after 7 days exposure. The early apoptotic cells recorded were as high as $2.16 \%$ with respect to Dose 3. Certain fraction of cells had already entered into the late apoptotic stage, marking about $0.36 \%$ in fishes exposed to the highest dose.

Results obtained after 7 days were analysed statistically using ANOVA and significant difference was found $(\mathrm{p}<0.05)$ in the percentage of early and late apoptotic cells in fishes exposed to Dose 1,2 and 3 respectively in comparison to sham injected control samples (Dose 0). Duncan's post hoc test revealed the presence of 4 subsets when early apoptotic cells were taken into consideration. This indicates that there was a significant difference in the percent contribution of early apoptotic cells with respect to all the 4 doses when they were compared pairwise. Variations were observed in results obtained with respect to cell populations which were in the late apoptotic stage. Significant difference was found $(\mathrm{p}<0.05$ at $\mathrm{df}=3,36)$ in the percent contribution of late apoptotic cells among fishes injected with four different doses (Table 2a). Duncan's post hoc test revealed the presence of 3 subsets. Fishes injected with Dose 0 and 3 belonged to a single subset, indicating that there was a significant difference between Dose 0 and the others when they were compared pairwise. Similar results were observed with respect to Dose 3. However, when fishes were injected with Dose 1 and 2 , they belonged to a single subset indicating that there was no significant difference between them when compared pairwise. Thus, a clear dose dependent pattern of cell death was observed after 7 days.

The same study was repeated after 30 days to understand and interpret the in vivo innate immune responses that might have triggered to curb the pathogenic effect of $A$. hydrophila. Results indicated a sharp decline in the percentage of early and late apoptotic cells in the fishes exposed to Dose 1, 2 and 3 respectively. When the cells in early apoptotic stage were compared after 30 days, there was presence of 3 subsets. Fishes injected with Dose 0 and 1 belonged to a single subset while fishes injected with Dose 2 and 3 belonged to single subset, each indicating a significant difference when they were compared with other doses. However, when cells in late apoptotic stage were taken up for study, they revealed the presence of only one subset indicating there was no significant difference among them when compared pair wise. Hence, study after 30 days showed a distinct pattern of recovery that had taken place in vivo with reference to the extent of cell damage and cell death and clearly reflects a strong innate immunity in these fishes.

Paired t-test ( 2 tailed) was performed considering the early apoptotic cells that were obtained after 7 and 30 days respectively (Table 2b). Significant difference was found $(p<0.05)$ for the early apoptotic cell populations between 7 and 30 days with respect to all the three doses. Thus, this study reveals both pathogenic effect of the potent native bacteria and also the in vivo immune response in heart of C. mrigala.

The apoptotic nature of $A$. hydrophila has been observed earlier in C. mrigala with reference to the vital 
Table 2. Evaluation of apoptotic potential of A. hydrophila (MTCC 646) in heart of C. mrigala. Single cell suspensions of heart cells from fishes exposed to different doses of the pathogen were analysed after 7 days for acute toxic effect and after 30 days for understanding the mode of recovery in these fishes.

(a)

\begin{tabular}{|c|c|c|c|c|}
\hline Sampling day & Dose of A. hydrophila & $\begin{array}{l}\text { Normal cells (\%) } \\
\text { (Annexin V-/PI-) }\end{array}$ & $\begin{array}{l}\text { Early apoptotic cells (\%) } \\
\text { (Annexin V+/PI-) }\end{array}$ & $\begin{array}{l}\text { Late apoptotic and necrotic } \\
\text { cells }(\%)(\text { Annexin } \mathrm{V}+\mathrm{PI}+)\end{array}$ \\
\hline \multirow[t]{4}{*}{7 days post-challenge } & Dose 0 (Sham injected control) & 99.95 & $0.25^{\mathrm{a}}$ & $0.04^{\mathrm{a}}$ \\
\hline & Dose $1\left(2 \times 10^{5} \mathrm{CFU} \mathrm{ml-}{ }^{1}\right)$ & 98.92 & $0.96^{\mathrm{b}}$ & $0.12^{\mathrm{b}}$ \\
\hline & Dose $2\left(2 \times 10^{6} \mathrm{CFU} \mathrm{ml}^{-1}\right)$ & 98.42 & $1.54^{\mathrm{c}}$ & $0.12^{b}$ \\
\hline & Dose $3\left(2 \times 10^{7} \mathrm{CFU} \mathrm{ml}{ }^{-1}\right)$ & 97.72 & $2.16^{\mathrm{d}}$ & $0.36^{\mathrm{c}}$ \\
\hline \multirow[t]{4}{*}{30 days post-challenge } & Dose 0 (Sham injected control) & 99.94 & $0.01^{\text {aa }}$ & $0.03^{\text {aa }}$ \\
\hline & Dose $1\left(2 \times 10^{5} \mathrm{CFU} \mathrm{ml} \mathrm{m}^{-1}\right)$ & 99.97 & $0.02^{\text {aa }}$ & 0.01 aа \\
\hline & Dose $2\left(2 \times 10^{6} \mathrm{CFU} \mathrm{ml}^{-1}\right)$ & 99.83 & $0.17^{\mathrm{bbc}}$ & $0.00^{\text {aa }}$ \\
\hline & Dose $3\left(2 \times 10^{7} \mathrm{CFU} \mathrm{ml}{ }^{-1}\right)$ & 99.49 & $0.5^{\mathrm{cc}}$ & 0.01 aa \\
\hline
\end{tabular}

(b)

\begin{tabular}{lllll}
\hline Type of cells & Sample groups & Dose 1 $($ Mean \pm SE) & Dose 2 (Mean \pm SE) & Dose 3 (Mean \pm SE) \\
\hline Early apoptotic cells & 7 days & $0.96 \pm 0.001$ & $1.54 \pm 0.001$ & $2.16 \pm 0.001$ \\
& 30 days & $0.02 \pm 0.001$ & $0.17 \pm 0.00$ & $0.51 \pm 0.00$ \\
& t value & $941^{*}$ & $841.4^{*}$ & $1082.14^{*}$ \\
\hline
\end{tabular}

* Significant ( $\mathrm{p}<0.05),(2$ - tailed).

Similar alphabets within column denote homogeneous means due to Duncan's test $(\mathrm{p}<0.05)$. Single alphabet in the columns denotes results analysed after 7 days while double alphabets depict results analysed after 30 days. Paired t-test was performed for early apoptotic cells for Doses 1,2 and 3 respectively for 7 and 30 days exposure. Mean \pm SE values are shown. Significant difference was observed in early apoptotic cell samples $(p<0.05$ ) collected after 7 and 30 days duration with respect to all the three doses.

organ in the body viz., liver(Datta Ray and Homechaudhuri, 2014) and immunocompetent organs like head kidney and spleen (Datta Ray and Homechaudhuri, 2016). A. hydrophila deploys a range of virulence determinants, which interact with the key components of cell death pathway of the host or interferes with the regulation of such transcription factors that monitor cell survival. This aims to evade, counteract or restrain host defenses. In conclusion, the findings of this study show that $C$. mrigala challenged with $A$. hydrophila at sublethal doses are physiologically impaired which was clearly evidenced by quantification of the oxidative stress biomarker (ROS) and assessment of the extent of cellular damage in the heart analysed using flowcytometry.

\section{Acknowledgements}

The authors are grateful to the Department of Zoology, University of Calcutta, West Bengal, India for providing facilities to carry out the research work. The first author was supported by a University Grants Commission (UGC) sponsored Minor Research Project (MRP).

\section{References}

Almeida, A., Cunha, A., Gomes, N. C. M., Alves, E., Costa, L. and Faustino, M. A. F. 2009. Phage therapy and photodynamic therapy: low environmental impact approaches to inactivate microorganisms in fish farming plants. Marine drugs, 7(3): 268-313.doi:10.3390 md7030268.
Bancroft, J. D. and Stevens, A. 1990. Theory and practice of histological techniques, $3^{\text {rd }}$ edn. Churchill Livingstone, Edinburgh, UK and New York, USA, 726 pp.

Bolwell, G. P., Butt, V. S., Davies, D. R. and Zimmerlin, A. 1995. The origin of the oxidative burst in plants. Free Radical Res., 23(6): 517- 532. doi: 10.3109/10715769509065273

Dash, S., Swain, P., Swain, M. M., Nayak, S. K., Behura, A., Nanda, P. K. and Mishra, B. K. 2008. Investigation on infectious dropsy of Indian major carps. Asian Fish. Sci., 21(4): 377-384.

Daskalov, H. 2006. The importance of Aeromonas hydrophila in food safety. Food Control, 17(6): 474 - 483. doi: 10.1016/j. foodcont.2005.02.009.

Datta Ray, S. and Homechaudhuri, S. 2014. Morphological and functional characterization of hepatic cells in Indian major carp, Cirrhinus mrigala against Aeromonas hydrophila infection. J. Environ. Biol., 35(1): 253 - 258.

Datta Ray, S. and Homechaudhuri, S. 2016. In vivo immune response of major immunocompetent organs in Indian major carp, Cirrhinus mrigala upon infection with Aeromonas hydrophila. The Clarion-International Multidisciplinary Journal, 5(1): 1-9. doi: 10.5958/2277-937X.2016.00001.0.

Dror, M., Sinyakov, M. S., Okun, E., Dym, M., Sredni, B. and Avtalion, R. R. 2006. Experimental handling stress as infection-facilitating factor for the goldfish ulcerative disease. Vet. Immunol. Immunopathol., 109(3-4): 279 - 287. 
Ellsaesser, C. F. and Clem, L. W. 1987. Cortisol induced haematologic and immunologic changes in channel catfish (Ictalurus punctatus). Comp. Biochem. Physiol., 87A (2): 405 - 408.

Gamaley, I. A. and Klyubin, I. V. 1999. Roles of reactive oxygen species: Signaling and regulation of cellular functions. Int. Rev. Cytol., 188: 203-255. doi.org/10.1016/S0074-7696 (08)61568-5.

Gbore, F. A., Oginni, O., Adewole, A. M. and Aladetan, J. O. 2006. The effect of transportation and handling stress on haematology and plasma biochemistry in fingerlings of Clarias gariepinus and Tilapia zillii. World J. Agric. Sci., 2 (2): $208-212$.

Genten, F., Terwinghe, E. and Danguy, A. 2009. Atlas of fish histology, $1^{\text {st }}$ edn. CRC Press, Boca Raton, Florida, USA, $224 \mathrm{pp}$.

Ghenghesh, K. S., Ahmed, S. F., El-Khalek, R. A., Al-Gendy, A. and Klena, J. 2008. Aeromonas - associated infections in developing countries. J. Infect. Dev. Countr., 2(2): 81-98.

Groff, J. M. and Zinkl, J. G. 1999. Haematology and clinical chemistry of Cyprinid fish: Common carp and goldfish. Vet. Clin North Am., Exot. Anim. Pract., 2 (3): 741 -746.

Greenwell, M. G., Sherrill, J. and Clayton, L. A. 2003. Osmoregulation in fish: Mechanisms and clinical implications. Vet. Clin North Am. Exot. Anim. Pract., 6(1): $169-189$

Harikrishnan, R., Balasundaram, C. and Bhuvaneswari, R. 2005. Restorative effect of Azadirachta indicab aqueous leaf extract dip treatment on haematological parameter changes in Cyprinus carpio (L.) experimentally infected with Aphanomyces invadans fungus. J. Appl. Ichthyol., 21(5): 410 - 413

Huizinga, H. W., Esch, G. W. and Hazen, T. C. 1979. Histopathology of red-sore disease (Aeromonas hydrophila) in naturally and experimentally infected largemouth bass Micropterus salmoides (Lacepede). J. Fish Dis., 2(4): $263-277$.

Mohanty, B. R., Sahoo, P. K., Mahapatra, K. D. and Saha, J. N. 2007. Innate immune responses in families of Indian major carp, Labeo rohita, differing in their resistance to Edwardsiella tarda infection. Curr. Sci., 92: 1270-1274.

Mohanty, B. R. and Sahoo, P. K. 2010. Immune responses and expression profiles of some immune-related genes in Indian major carp, Labeo rohita to Edwardsiella tarda infection. Fish Shellfish Immunol., 28(4): 613-621.

Marques, I. J., Leito J. T. D., Spaink, H. P., Testerink, J., Jaspers, R. T., Witte, F., Van Den Berg, S. and Bagowski, C.P. 2008. Transcriptome analysis of the response to chronic constant hypoxia in zebrafish hearts. J. Comp. Physiol. B: Biochem., Syst. Environ. Physiol., 178(1): 77 - 92.

Oter, S., Jin, S., Cucullo, L. and Dorman, H. D. 2012. Oxidants and antioxidants: friends or foes? Oxidants and antioxidants in Medical Science, 1(1): 1 - 4.
Pal, J. and Pradhan, K. 1990. Bacterial involvement in ulcerative condition of air-breathing fish from India. J. Fish Biol., 36(6): 833 - 839.

Raida, M. K. and Buchmann, K. 2008. Development of adaptive immunity in rainbow trout, Oncorhynchus mykiss (Walbaum) surviving an infection with Yersinia ruckeri. Fish Shellfish Immunol., 25(5): 533-541.

Raida, M. K. and Buchmann, K. 2009. Innate immune response in rainbow trout (Oncorhynchus mykiss) against primary and secondary infections with Yersinia ruckeri. Dev. Comp. Immunol., 33(1): 35 - 45.

Reyes-Becerril, M., Tovar-Ramirez, D., Ascencio-Valle, F., Civera-Cerecedo, R., Gracia-Lopez, V., Barbosa-Solomieu, V. and Esteban, M. A. 2011. Effects of dietary supplementation with probiotic live yeast Debaryomyces hansenii on the immune and antioxidant systems of leopard grouper Mycteroperca rosacea infected with Aeromonas hydrophila. Aquac. Res., 42(11): 1676 - 1686.

Rodriguez, I., Novoa, B. and Figueras, A. 2008. Immune response of zebrafish (Danio rerio) against a newly isolated bacterial pathogen Aeromonas hydrophila. Fish Shellfish Immunol., 25(3): 239 - 249.

Saha, D. and Pal, J. 2000. Bacteriological studies on fishes affected with epizootic ulcerative syndrome. Asian Fish. Sci., 13(4): 343-356.

Sahu, S., Das, B. K., Mishra, B. K., Pradhan, J. and Sarangi, N. 2007. Effect of Allium sativum on the immunity and survival of Labeo rohita infected with Aeromonas hydrophila. J. Appl. Ichthyol., 23(1): 80-86.

Saksida, S., Constantine, J., Karreman, G. A. and Donald, A. 2007. Evaluation of sea lice abundance levels on farmed Atlantic salmon (Salmo salar L.) located in the Broughton Archipelago of British Columbia from 2003 to 2005. Aquac. Res., 38: 219-231

Scott, A. P. and Ellis, T. 2007. Measurement of fish steroids in water - a review. Gen. Comp. Endocrinol., 153(1 - 3): 392-400.

Shao, Z. J. 2001. Aquaculture pharmaceuticals and biologicals: current perspectives and future possibilities. Adv. Drug Deliv. Rev., 50(3): 229 - 243.

Steinbach, C., Kroupova, H. K., Wahli, T., Klicnarova, J. and Schmidt-Posthaus, H. 2016. Histopathological alterations of the heart in fish: proposal for a standardised assessment. Dis. Aqua. Org., 118: 185-194. https://doi.org/10.3354/ dao02971.

USEPA 2001. Aeromonas in finished water by membrane filtration using Ampicillin-Dextrin agar with Vancomycin (ADAV), United States Environmental Protection Agency (USEPA), Washington, DC, USA.

Ventura, M. T. and Grizzle, J. M. 1988. Lesions associated with natural and experimental infections of Aeromonas hydrophila in channel catfish, Ictalurus punctatus 
(Rafinesque). J. Fish Dis., 11(5): 397-407. doi: 10.1111/ j.1365-2761.1988.tb00735.x.

Vivekanandhan, G., Hatha, A. A. M. and Lakshmana perumalsamy, P. 2005. Prevalence of Aeromonas hydrophila in fish and prawns from the seafood market of Coimbatore, South India. Food Microbiol., 22(1): 133-137.
Wahli, T., Knuesel, R., Bernet, D., Segner, H., Pugovkin, D., Burkhardt-Holm, P., Escher, M. and Schmidt-Posthaus, H. 2002. Proliferative kidney disease in Switzerland: current state of knowledge. J. Fish Dis., 25(8): 491-500.

Zar, J. H. 1999. Biostatistical analysis, $4^{\text {th }}$ edn. Prentice Hall, Upper Saddle River, New Jersey, USA. 